\title{
Véletlenek márpedig nincsenek (?) Interjú Beluszky Pállal
}

\section{Incidences just would not happen (?) Interview with Pál Beluszky}

\author{
JANKÓ FERENC
}

Beluszky Pállal 2003-ban a Korall társadalomtörténeti folyóirat számára készült egy interjú, a kérdező akkor Rácz Lajos volt. Az interjút végigolvasva az olvasó csodálkozhat, hogy mennyi látszólagos véletlen, külső hatás és körülmény határozta meg Beluszky Pál életét. A lakóhely- és a pályaválasztás, az FKI elhagyása vagy az RKK-ba kerülés az FKI-ba való visszatérés helyett. Helytálló ez a sarkítás? Ha a kutatói pályára tekintünk, annak befutásához viszont markáns ambícióra lehetett szükség. Hogyan formálódott Tanár Úr kutatói ambíciója, miképp erősödött meg az az elhatározás, hogy kutatói pályát fusson be?

Én úgy tapasztalom, hogy a mai generáció sokkal tudatosabban építi a pályáját, mint tettük azt mi jó ötven évvel ezelőtt. Egyrészt kevésbé van az ember kiszolgáltatva különböző korlátoknak, a lehetőségek is bővültek, és sokkal szerteágazóbbak. A mi korunkban, ha valaki tudományegyetemre iratkozott be, akkor a tanításon kívül nem nagyon volt más lehetősége. Tehát nem is nagyon gondolkodtunk előre, hogy az ember hol helyezkedik el. Másrészt kevés lehetőség adódott a saját elképzelések megvalósítására, úgy, hogy sokkal több volt a véletlen, és kevesebb a tudatos pályaépítés.

Az én esetemben ez például azt jelentette, hogy nekem eszem ágában sem volt geográfusnak lenni, még történésznek sem, leginkább valahol az irodalom környékén tudtam elhelyezni magam, az irodalomtörténet, vagy valamelyik irodalomtudomány vidékén. De az akkori felvételi rendszer merevsége volt az, amely végül egyrészt Debrecenbe küldött engem - én az ELTE-re jelentkeztem - másrészt az irodalom szaktól fokozatosan csúsztam át a geográfia irányába. Egy ideig - mint történelem-földrajz szakos hallgató - inkább a történelem keretei között tudtam volna elképzelni a pályámat, s tulajdonképpen a véletlenek juttattak a geográfia területére.

A debreceni történeti intézet ugyan színvonalas tanári gárdával rendelkezett, de valahogy távol állt tőlük az, hogy a hallgatókkal közvetlenül foglal-

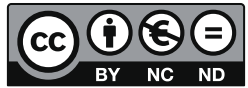


kozzanak. Míg a földrajz szaknál ez sokkal intenzívebb volt, már csak azért is, mert gyakran jártunk terepgyakorlatra, tanulmányi kirándulásra. A földrajzi intézetben még a hallgatóknak is - akkor még kevesen voltunk - volt külön asztala; ezek a sokszor apróságnak tűnő személyes és véletlenszerü dolgok is azt eredményezték, hogy mire negyedéves lettem, már inkább a földrajz iránt érdeklődtem, noha még a szakdolgozatom témaválasztása is valami olyasmi volt, hogy azért onnan is minden irányban el tudtam volna indulni. A szakdolgozatom témája ugyanis a 19. századi magyar geográfia története volt.

Végül még az is véletlennek tekinthető, hogy a Magyar Földrajzi Társaság akkoriban pályázatokat hirdetett fiatal kutatók, illetve középiskolai tanárok számára, tehát tudományos minősítéssel rendelkezők nem vehettek azokon részt. Ahogy emlékszem, a következő két évben egyszer szereztem első, egyszer második helyet ezen a pályázaton, s ez - úgy tűnik - aztán végleg a földrajz felé irányított engem. Tehát a véletlenek igen gyakran kijelölték pályámat.

Utólag még azt is lehetne mondani, hogy a tény, hogy én ifjúkoromban végiglaktam az egész országot - Szolnokon születtem, aztán az akkor a legnagyobb magyar falunak nevezett Orosházán kezdtem cseperedni, majd az akkori kurzus dédelgetett vidéki városában, Szegeden voltam nagyon ifjú gyerek, majd a manapság oly gyakran emlegetett Devecserben jártam az elemi iskoláimat, végül egy nagyon érdekes dunántúli polgárvárosban, Nagykanizsán folytattam, végülis Budapesten és Tiszafüreden keresztül jutottam Debrecenbe - ez puszta véletlen. De az fontos, hogy még most is visszaemlékezve ezekre a stációkra, az adatokon, az információkon túl, valahogy könnyebben el tudom képzelni egy vidéki kisváros, egy olyan kis járási székhely, mint Devecser életét, vagy Tiszafüredet az ötvenes években. Tehát ezeket az ismereteket valamilyen formában ma is tudom használni, teljesen függetlenül attól, hogy természetesen nem azért laktam végig az országot, hogy végül geográfus legyek.

Volt szó arról, mikor negyedéves voltam, hogy a debreceni egyetemen maradhatok, de ez az a korszak volt, amikor rendkívül ritkán nyílt alkalom erre. A negyvenes évek legvégén, az ötvenes évek elején futott fel az egyetemi oktatás, erősen növekedett a hallgatók száma, ezzel egyidejűleg az oktatók száma is, de az ötvenes évek végén, a hatvanas években egyetemi oktatói állást a legritkább esetben lehetett megpályázni.

A nyertes pályázatok voltak a kulcstényezők a pályamódositásban?

Talán. Ugyanis három év középiskolai tanítás után adtam be pályázatot aspirantúrára, és feltehetően ennek az elbírálásakor valamilyen súllyal latba esett az a két nyertes pályázat is. $\mathrm{S}$ tulajdonképpen így kerültem aztán kutatói pályára.

Volt-e szerepe a kutatói pályaválasztásában, késóbb a pályaformálásban példaképeknek? Legyenek azok egyetemi oktatók Debrecenböl, szakirodalomból megismert mintaadók, vagy késóbb a szakmában megismert nagy egyéniségek. 
Kifejezetten példaképet, vagy olyan személyiséget, aki elindított ezen a pályán, nem nagyon tudok az emlékeimből előhozni. Az ötvenes években, amikor én a debreceni egyetemen jártam, a földrajz tanszék igen erős volt a természeti földrajz terén. Ugye Kádár László professzor, vagy ott tanított akkor még Kéz Andor, és akkor még fiatal oktatóként, de már ott volt Borsy Zoltán és Pinczés Zoltán, akik aztán évtizedeken keresztül fémjelezték a debreceni egyetem természetföldrajzi oktatását. Az akkor gazdaságföldrajznak nevezett társadalomföldrajzot kevesen tanították. Volt ugyan közöttük egy kiváló pedagógus, Csinády Gerő, ${ }^{1}$ akiről manapság igen keveset tudnak a fiatal geográfusok, de ő kutatóként más területekkel foglalkozott, mint jómagam: pollenanalízissel és tudománytörténettel is, úgyhogy őrá jó szívvel emlékezem, sokat tanultam tőle, de kutatói példaképnek nem említeném.

Két embert még meg kell említenem: Szabó Istvánt, a történészt, akivel ugyan közelebbi kapcsolatba nem kerültem. Ő a középkori magyar falvakkal sokat foglalkozott, s a későbbiekben a müveit használtam, olvastam, de mint ember és tudós igen tisztelt személyiség volt, nemcsak általam; valóságos kultusza volt akkoriban Debrecenben. A történeti tanszékek oktatóiból sugárzott a Szabó István iránt való rokonszenv és megbecsülés.

Még kell egy nevet említenem, akivel nem kerültem személyesen kapcsolatba, nem tarthatom magam tanítványának: ez Erdei Ferenc. Amikor hallgatója voltam a debreceni egyetemnek, a gazdasági földrajz meglehetősen száraz, statisztikai adatokkal teletömött, valóban leíró jellegü tantárgy volt. Markos Györgynek a tankönyve - amiből ugyan nem tanultunk, egy-két évvel később jelent meg - de jól példázza ezt a gazdaságföldrajzi irányzatot. Rendkívüli élményt jelentett számomra Erdeinek néhány korai műve, a „Futóhomok”, a „Magyar város”, a „Magyar falu”, a „Magyar tanyák”, amelyekben a települések élete sokkal gazdagabban bontakozott ki. Ő a társadalmat vizsgálta elsősorban, noha szoros kapcsolatban volt a földrajzzal. Ismerjük az elhíresült Mendöl-Erdei vitát, amely mutatja a szoros kapcsolatot és átfedést a két tudomány között. Úgyhogy az én számomra nagyon megkapóak, lenyügözők voltak az ő munkái.

Még talán annyit említenék - ha már a példaképekről esik szó -, hogy amikor én hallgató voltam, Enyedi György még nem tanított Debrecenben - a végzésem után, ha jól emlékszem, két évvel került a debreceni tanszékre -, tehát őt szintén nem ismertem személyesen. A későbbiekben azonban évtizedekig, tulajdonképpen a mai napig valamilyen formában összefonódott a pályánk. Tehát egy helyen dolgoztunk, sok közös munkánk is volt, de a pályám elején nem voltunk kapcsolatban, nem lehetett a példaképem.

Az egyetemi oktatás majdhogynem kimaradt az életéből. Mégis Tanár Úrnak szólítjuk sokan, hiszen írásaival vagy akár stílusával példakép lehet sokak számára. Mit gondol a mester-tanítvány kapcsolatról, milyen szerepet töltött be az Ön életében? 
Az egyetemekkel való kapcsolatomra térve, az meglehetősen ritka volt, esetleges. Egyetlen egy helyen sem tanítottam hosszabb ideig, legfeljebb óraadóként, vagy egy-egy előadás erejéig kerültem kapcsolatba az egyetemi oktatással. Ennek egyrészt az az oka - úgy gondolom -, hogy írásban jobb vagyok, mint szóban. Nem is ambícionáltam különösképpen az egyetemi oktatásban való részvételt. Azonban a mai napig furcsállom - nem panaszként mondom, mert kiválóan éreztem magam kutatóként is a bőrömben -, hogy majd' fél évszázados pályám alatt igazán egyetlen egyetem vagy főiskola nem kívánt rávenni arra, hogy tartósan és intézményesen okítsak. Ennek nem tudom pontosan az okát, illetve talán éppen a mester-tanítvány kapcsolattal összefüggésben ennek egyik szálát ki tudom bontani. Kissé zárkózott alkat vagyok, kialakult bennem, nem a kívülállás, hanem a távolságtartás ethosza. Jól érzem magam ebben a pozícióban, ami azt is jelenti, hogy igazán szorosan egyetlen csoportnak sem lettem a tagja, egy kicsit mindig kívülállónak éreztem magam, és valószínűleg érződött azoknál is, akik esetleg ajánlatokat tehettek volna. De ez azért nehezen magyarázható. Én amikor olykor-olykor előadást tartottam, és úgy éreztem, hogy az előadás nem sikerült rosszul, akkor kifejezetten kellemes érzés töltött el. Az, hogy például az ELTE-n mint előadó talán soha nem fordultam elö, lehet, hogy furcsán hangzik. Nem mondom, hogy én jobbat, többet tudtam volna mondani, de mindenképpen mást, mint mások. Úgyhogy így alakult az egyetemekkel való viszonyom.

Ez a mester-tanítvány viszonyra is nyilvánvalóan kihat. Mint mondtam, nem igazán volt olyan személy az életemben, akire egyértelműen azt mondanám, hogy a Mesterem volt. Az egyetemekkel való laza kapcsolat azt eredményezte, hogy tanítványokat sem nagyon tudok megnevezni, legalábbis olyanokat, akikkel személyes kapcsolat, együttdolgozás során alakult volna ki ez a kapcsolat. Itt a munkahelyemen néhány fiatal kutatóval van olyan kapcsolatom, olyan viszonyom, amelyre talán ez a mester-tanítvány megnevezés illik.

Közelitsünk a földrajz fejlődését firtató kérdésekre: egy szakma, így a geográfia fejlödésének is egyik motorja a generációs konfliktus. Hogyan élte meg Tanár Úr ezt kutatói pályája elején, derekán, és hogy látja most e kérdést?

A pályám elején, ami az ötvenes, hatvanas, talán még a hetvenes évekre is esett, ez talán abban nyilvánult meg, hogy az idősebb generáció úgymond elfoglalta azokat a helyeket, amelyekre esetleg mások, adottságaik, teljesítményük alapján pályázhattak volna. Én ezt így nem éreztem, mert aztán néhány évi középiskolai oktatás után az akadémiai pályára kerültem. Ekkor, tehát a hatvanas, hetvenes években ez a kérdés olyan szempontból nem nagyon merült fel, hogy a fiatal generáció merőben újat hozott volna a geográfiába. Nem mutatkozott egyértelműen más, újabb szemléletűnek a fiatalabb generáció, noha természetesen voltak olyan tudományos innovációk, amelyek megjelentek, de nagyjából ugyanazt képviselték azok, akik bekerültek, mint az elődeik.

Feltehetően az elmúlt években, évtizedben ez a helyzet megváltozott. A 
mai fiatal generációra nyugodtan rá lehet mondani, a legjobbakra mindenképpen, hogy új szemléletet, új lehetőségeket, új irányzatokat, ismereteket jelentenek a geográfiában. Manapság, ha egy magamfajta, félig-meddig „visszavonuló” kutató helyébe egy tehetséges ifjú lép, ez nemcsak személyi változást jelent, hanem valóban kihat a geográfia fejlődésére is. Az új generáció ismeretei jóval szélesebb körüek, kapcsolatrendszere is más, tagjai már nagyon korán, egyetemi hallgató korukban belekerülhetnek a nemzetközi tudományos életbe. Nyelvismeretük lehetővé teszi, hogy a külföldön megjelenő tudományos irányzatokat, iskolákat megismerjék, alkalmazzák. Nekik természetesen már mindaz a lehetőség, amit a számítógép, az internet képvisel, kézenfekvően rendelkezésre áll. Míg én például a mobiltelefon használatával küzdök. Tehát ez a most vagy a közeljövőben lezajló generációváltás bizonyára kihat, és jó irányban hat ki a geográfia fejlődésére. Ráadásul azért az elmúlt években nagyobb lehetőség is volt a generációcserére, egyrészt az a korosztály, amit én is képviselek, lassan visszavonult a tudománytól, nyugdíjba ment, emellett az álláshelyek megszaporodtak az egyetemeken, főiskolákon, viszonylag sokan bekerülhetnek a geográfia mühelyeibe, s a legjobbak szerintem jó irányba fogják a geográfiát lökni. Hozzáteszem, noha én ezekkel az ismeretekkel, képzettséggel már nem rendelkezem, de jóleső érzés látni, hogy ez az ifjú generáció nemcsak ifjú, hanem egy új minőséget képvisel a geográfiában.

Nagyon tudatosan megrendezettnek tünik „visszavonulása” az aktív tudományos életból. A „Maradékok boltja” a TéT hasábjain érdekes színfolt a tudományos palettán, de idesorolhatjuk talán már a „Vég kiárusítás” köteteket is, amelyek első része még 1992-ben jelent meg. Mi volt itt a motiváció?

Van ebben bizonyos játék is. Mindig hálás voltam a sorsnak, hogy olyan pályán működöm, amelyet valamilyen életkori határ nem zár le egyértelmüen, markánsan, mereven. Jelenleg már nyugdíjas vagyok, de ez nem jelenti azt, hogy ne tudnék részt venni a tudományos életben. A Tér és Társadalomban publikáltam néhány szösszenetet olyan címmel, hogy „Egy visszavonuló levelei”, vagy ez a „Vég kiárusítás”, ebben volt bizonyos „játék”, „szerepjátszás" - mondjuk így.

A „Vég kiárusítás” esetében inkább az vezetett, hogy szembe kell nézni a geográfiát müvelőknek azzal, hogy ez egy rendkívül szűk körben ható tudomány. Egy-egy folyóiratcikket néhány tucat, esetleg, egy-kétszáz ember olvas el. Úgyhogy én arra gondoltam, hogy ha egy kötetben összegyűjtöm ezeknek a korábban elkövetett tanulmányaimnak egy részét, akkor ezzel talán új olvasókat is szerzek. Hozzájárult ehhez az a tapasztalat is, hogy manapság a fiatal generációról - sok jót mondtam róla - azt azért nem lehet elmondani, hogy hosszasan és buzgón kutakodna a régi folyóiratokban, régi irodalomban. Tehát, ha az ember újra közreadja, akkor talán van arra esély, hogy még néhányan elolvassák. Földrajzi folyóiratokat, új folyóiratszámokat 
kapva néha megnézem, hogy fiatalabb pályatársaim kikre és milyen tanulmányokra hivatkoznak. Volt olyan szám, hogy két-három évre ment vissza a hivatkozásoknak az ideje. Tehát tulajdonképpen azt lehet mondani hogy a fiatalabb generációnak egy része akkortól ismeri a tudományt, amikortól valamilyen formában ő is részt vesz benne.

Amitől tényleg szeretnék visszavonulni, az inkább a szereplés. A kolléganőmet, aki titkárkodik körülöttem, már meg is kértem, hogy azonnal utasítson vissza mindent, ami rajta keresztül eljut hozzám. De ebben még nem igazán értem el sikereket. A szerepléstől már szeretnék visszahúzódni, a geográfia művelésétől nem. Még mindig van számos elképzelésem, tervem, igaz, hozzá kell tenni (amit régen nem hittem volna), hogy az ember teljesítöképessége a korával csökken egy idő után. Nyilván az emberben az ambíció is csökken valamelyest. Úgy gondolja, hogy ő már sok mindent megcsinált, most egy tanulmány ide vagy oda, az már nem befolyásolja igazán a pályájának a megítélését.

Tekintsünk végig ezen a tudományos pályán! Melyek voltak a leginkább kedves kutatási témák?

Meglehetősen sok mindennel foglalkoztam az elmúlt fél évszázad alatt, noha többnyire azért a településföldrajz keretei között maradtam. Ezek között a témák között a szívemhez legközelebb talán az Alföld-jelenséggel kapcsolatos vizsgálódások állnak, ennek az összegzése a nem éppen szerencsés című, a „Nagyalföld történeti földrajza” c. kötetben jelent meg. Kedvenc témám volt ez, főleg, mert a történettudományban is vizsgálódni kellett. Olyan dolgok is felmerültek az alföldi mezővárosok kapcsán, mint például a protestantizmus és a mezővárosok lakossága, társadalma közötti kapcsolat. A protestáns etika - amely eléggé közismert téma - valóban jelentkezett-e az alföldi mezővárosok esetében vagy sem?

Valamiféle elképzelést kialakítottam az Alföldről. Azt, hogy ez nem kizárólag egy elmaradott táj, nem lehet az elmaradottsággal, az időbeli megkésettséggel magyarázni az alföldi jelenségeket. Azt, hogy ez a másság nem valamiféle véletlenszerü tényezőknek az eredménye, nem azoknak a kombinációjából fakad, hanem egy sajátos társadalomfejlődési út, amely a kelet-európai társadalomfejlődési úttal nem rokonítható, nem abból fakadnak az Alföld sajátosságai. Noha a felszínen erre utaló jelek volnának: az iparosítás, a valódi polgárság hiánya, gyengesége, és így tovább. De nyilvánvalóan nem is a tipikus nyugat-európai út ez. Hogy valamiféle elméleti keretbe sikerült azt a sokféle jelenséget összefoglalni, ami az Alföld kapcsán észlelhető, az alföldi társadalom és településhálózat sajátosságait, kedvenc témámmá tette az alföldi sajátosságok vizsgálatát.

A másik nagyon régi, s csak kis részben megvalósított tervem, hogy elvégezzem a földrajz egyik klasszikus feladatát Magyarország tájaival kapcsolatban, mégpedig a „maguktól adódó” tájakról (tehát nem a közigazgatási egységekről). 
Hogy készítsek valamiféle, a földrajz kereteit, ismeretanyagát bővítő vagy feszegető leírásokat, amelyek nagyon hiányoznak a magyar geográfiából. Nagyon sok adósságom van ezen a téren. Tulajdonképpen az Őrségről írt kötetemre tudnék hivatkozni, s néhány kisebb lélegzetű tanulmányra. Még mindig nem tettem le végleg arról, hogy ezen a téren valamilyen eredményt elérjek.

Még egy témát említenék, ez a hetvenes években többekkel együtt végzett kutatás a hátrányos helyzetű vagy elmaradott területekről. Ez volt az a terület, ahol jómagam is közel kerületem a sokak által a földrajz fontos feladatának tartott irányzathoz, törekvéshez, amely a földrajznak a gyakorlati életben való hasznosítását, a területi folyamatokra való hatásgyakorlást is fontosnak tartja. Ebben az időben kijelöltük azokat a területeket, amelyek a területi fejlődés, az ott élő társadalom állapota alapján hátrányos helyzetüeknek tarthatók. Ez még azért is jelentősnek mondható-ítélhető vizsgálat volt, mert ebben az időben arról nem volt szokás, divat vagy szabad beszélni, hogy van az országban szegénység, van társadalmi igazságtalanság és így tovább.

Ez a kutatás tehát bizonyos fokig olyasmit is vállalt, amely túllépett a geográfia szüken értelmezett feladatán. Hogy ez a munka nem lett volna haszontalan és felesleges, azt az mutatja és bizonyítja, hogy az általunk kialakított-lehatárolt hátrányos helyzetü területek szinte pontosan egybeesnek azokkal a területekkel, amelyek ma is rendkívül súlyos társadalmi-szociális gondokat jelentenek. Mi akkor megfogalmaztunk bizonyos javaslatokat is. Természetszerüleg (ha ez természetszerünek vehető!) kevés sikerrel és hatással. Lehet, hogy a rendkívül kedvezőtlen helyzetű területek kialakulásához vezető folyamatokat nem sikerülhetett volna teljességgel megváltoztatni, de talán egy korai beavatkozás valamelyest kedvezőbb helyzetet eredményezett volna. Ez nem következett be, de a kísérletnek a létjogosultságát bizonyítja az, hogy ma ugyanezekkel a problémákkal - csak sokkal súlyosabb kifejletben - kell szembenézni a geográfiának, meg persze az ország egészének, a társadalomnak is.

Végigtekintve most a geográfia utóbbi bő fél évszázadán, amelynek alakitásában Tanár Úr is tevékenyen részt vett, hogyan látja azt az utat, amelyet tudományunk bejárt? Eljutott-e valahonnan valahova a földrajz?

Kétségtelenül változott a földrajz, és tett is kísérleteket arra, hogy a vele szemben megfogalmazott legfontosabb kritikát valahogy tompítsa. Ez a kritika mindenekelőtt abban állt, hogy a földrajz erősen leíró jellegű tudomány. Ezek közé a „kitörési” kísérletek közé tartozott például az ötvenes, hatvanas években az, hogy sokkal inkább támaszkodott a közgazdaságtan eredményeire. Csak zárójelben, és ennek az irányzatnak a motivációját érzékelendő említem meg, hogy valamikor a hatvanas években én is komolyan foglalkoztam azzal, hogy közgazdászdiplomát is szerezzek. Mert valóban vonzó volt az a lehetőség vagy az a remény, feltételezés, hogy a közgazdaságtan sokkal inkább kemény adatokkal dolgozó oknyomozó tudomány, mint a földrajz. Tehát 
ezeknek az ismereteknek, módszereknek a geográfiában való alkalmazása a geográfiát is oknyomozóbb tudománnyá tehetné.

A hetvenes években jelentek meg aztán a statisztikai, matematikai módszerek - magam is hódoltam egy ideig nekik, talán szintén túlbecsülve azokat a lehetőségeket, amelyeket ezek a módszerek nyújtottak, vagy reményeink szerint legalábbis nyújthattak volna. Önmagában ez a leíró jelleget nem változtatta meg, legfeljebb a leírás lett precízebb, okadatoltabb, tudományosabb; a leírást akár modellekbe foglalhattuk.

Ezután bizonyos szakadás következett be a társadalom területi folyamatait vizsgáló tudományokban. Nevezetesen az, hogy megjelent a regionális tudomány. A nyolcvanas években intézményesült is, létrejött a Regionális Kutatások Központja, lett folyóirat, társaság, az akadémián belül Regionális Tudományos Bizottság és így tovább. A geográfusok egy része is „átment” ebbe az új tudományágba, vagy legalábbis annak az intézményeibe.

Arról vita folyik, talán a mai napig, hogy egyáltalán szükség volt-e arra, hogy a területi folyamatok, a társadalom területiségének vizsgálata részben kilépjen a geográfia köréből, és egy új tudományágat hozzon létre. A geográfia ugyan később részben megújult, de minőségileg nem biztos, hogy új útra tért. Közben a társadalomtudományok egy egész sor elméletet előállítottak, módszereikben, szemléletükben, forrásanyagukban a müvelt témák területén nagyot léptek előre, s én úgy érzem, hogy a geográfia ezt nem követte. Nem kerültünk közelebb a „valódi” társadalomtudományokhoz az elméleti megalapozottság, a szemlélet terén. Hogy mást ne mondjak, a történettudomány - úgy érzékelem - lényegesen előttünk jár.

Úgy látom, hogy épp a közelmúltban történt, napjainkban történik azért egy lényeges reménykeltő változás: a fiatal generáció - legalábbis a jobbjai már belenő egy a társadalomtudományokhoz közelebb lévő geográfia kereteibe, légkörébe. Ma már nagyon komoly társadalomtudományi elméletekkel felvértezett, azokon alapuló, azokat használó tanulmányok is megjelennek. Én a geográfia legnagyobb adósságát abban láttam és látom, hogy nem tudta követni mindazokat az elméleti és szemléletbeli változásokat, amelyek a társadalomtudomány egészét jellemezték. Egy történész és egy kultúrantropológus vagy szociológus sokkal könnyebben megérti egymást, mint egy földrajzos és az előbb említett tudományágak képviselői. Ez azt is eredményezi - mondjuk meg őszintén -, hogy a geográfia presztízse a tudomány egészében, a társadalomtudományok körében nem túl magas. Meg a társadalomban sem túl magas, összehasonlítva mondjuk a történettudomány presztízsével. Vagyis e téren - hogy eljutott-e valahonnan valahová a geográfia - most tesz reménykeltő lépéseket az előrejutás érdekében.

Ide kapcsolódva: melyek azok a feladatok, amelyeket napjaink társadalmi folyamatai szánnak a társadalomföldrajznak? Milyen kérdések megválaszolását várja el a humán geográfiától korunk társadalma, ahhoz, hogy ez a presztízs növekedjen? 
Érdekes módon én nem is annyira a tudományos feladatokat említeném elöször, hanem azt, hogy a társadalomtudomány mellett valahogy a szélesebb - ahogy régen mondani szokták, a művelt - olvasói körhöz is közelebb jusson a geográfia. Ehhez kellene többek között az az ismeretterjesztés nevü müfaj, amely a legtöbb tudományágban megvan. Ezt a geográfia is művelje, és ennek legyen presztízse! Ennek ma az úgynevezett akadémiai pályákon alig van becsülete. Presztízse a tudományos fokozatok szerzésének, az impakt faktoros folyóiratokban megjelenő cikkeknek van, de ha valaki írna egy könyvet, bármiről: a magyar mezővárosokról, az ország tájairól, területi különbségeiről és így tovább, amely nem a teljes tudományos apparátus felvértezettségével lépne színre, hanem épp a közérthetőségével, annak a presztízse - „tudományos” körökben - jóval kevesebb volna, mint egy „tudományos" münek. Említettem, hogy régi tervem a "tájak" ismertetése amit én ugyan már sohasem fogok befejezni, vagy elörejutni benne. De szerintem, ha ilyen könyvek megjelennének, elképzelhető, hogy a presztízse nőne ennek a tudománynak. Most elbizonytalanodtam, mert próbáltam néhány ilyen kiadványt szerkeszteni, de a legteljesebb visszhang nélkül maradtak ezek. Tehát nem biztos, hogy ezután ha valaki írna egy könyvet az Ormánságról, azt vinnék, mint a cukrot. De meg kellene próbálni.

A másik tényleg tudományos feladat talán az lenne, hogy azoknak a nagy folyamatoknak, amelyeket mi felében-harmadában ismerünk - migráció, foglalkozási átrétegződés - rendkívül sok helyi vonzata és helyi megnyilvánulása van; igazából ezeket a folyamatokat megismerni - és pláne befolyásolni - akkor tudnánk, ha ezt a sok folyamatot ismernénk. Az elméleti megközelítéssel felvértezve sok empirikus vizsgálatot kellene végeznünk, és gondoskodni kéne arról, hogy ezek az empirikus vizsgálatok valamikor egy szintézis formájában összegződjenek. Kevés ilyenről tudok.

Néhány szintézis, nem feltétlenül a földrajz, hanem teszem azt a regionális tudomány által végzett szintézis - mondjuk meg őszintén - többnyire statisztikai adatokra és közigazgatási egységekre vonatkozó információkra épül. S amikor egy-egy ilyen helyszíni, beható empirikus vizsgálat eredményeivel szembesülünk, akkor látjuk, hogy milyen rengeteg változata van bizonyos folyamatoknak, és ezek az empirikus vizsgálatok rámutatnak az okokra is. Mert vannak ugye nagy elméletek, hogy mi vonzza vagy mi alakítja a migrációt, de hogy ez ténylegesen egy-egy család esetében hogy zajlik le, erről azért keveset tudunk. Tehát egyrészt empirikus ismeretekre továbbra is szükség van, ezeket valahogy elméleti keretekbe kellene foglalni, szintetizálni, és végső lépésként ezeket a szintetizált eredményeket közérthetően eladni. Eladni más szakmáknak - félve mondom, hogy az ország életét irányítóknak -, mert különösebb érdeklődést nem mutatnak ezen eredmények iránt. 
Ha mostanság rendeznék össze „egy regionális kutató" életmüvét a Földrajzi Félreértesitő számára, milyen bibliográfiai tételek kerülnének be a listába az utóbbi szük harminc esztendőbool?

A Földrajzi Félreértesítőnek az ötlete az volt, hogy egy geográfus, egy regionális kutató a piac igényeit, meg a politikai elvárásokat hogyan tudja követni tudományos munkája során. Akkor én most - engedve a kérdező pressziójának - ezt a gondolatsort folytatom. A változás annyi, hogy míg a tudományos kutatónak korábbi pályáján többnyire egy „trendhez” kellett igazodnia, ma differenciálódtak az elvárások. Íme néhány tanulmánycím a választékból:

- Azért a körözött mégis vörös

- A Duna vonalra támaszkodó nemzeti védvonal a brindza ellen

- Ha unod a Túró Rudit, válaszd a camembert-et

- Multinak írót, magyarnak túrót

- Magyar nemzettest térbeli transzgressziója ill. regressziója a tarhó-kefír fogalomváltás alapján

- Az aludttej is merjen nagyot álmodni

- Rokfort nélkül is van élet a Duna-Tisza táján

- Nemzetépités gomolyával

- A fajlagos gomolyafogyasztás kistérségi különbségei és kapcsolata a 2006-os választási eredményekkel

Az interjút Jankó Ferenc készítette 2011. április 20-án.

\section{Jegyzet}

1 Csinády Gerő (1902-1970). Lásd Mező Szilveszter: Templommá vált tanterem. Egy tudós tanár életútja a Nyárád partjától a debreceni nagyerdőig. Tiszántúli Történész Társaság, Balmazújváros-Debrecen, 2010, 112 p. Uő: Elfelejtett geográfusok elfeledett kutatója: Csinády Gerő. Természet Világa 142. (2011) 4., 189-190. 